\title{
2 Welfare state redistribution between overlapping generations - normative theories applied to two contemporary debates
}

\author{
Axel West Pedersen and Mi Ah Schoyen
}

\section{Introduction}

The British sociologist Seebohm Rowntree famously pointed out how, before the advent of the modern welfare state, the risk of falling into poverty was particularly concentrated in both ends of the life cycle: during childhood and child rearing and in old age (Rowntree, 1901). One of the key functions of the modern welfare state is to help avoid this "poverty cycle" by transferring economic resources to families with children and to the elderly.

The elderly, but increasingly also children, are the main recipients of cash and in-kind transfers from the welfare state (Daly, 2018; Kohli, 2006). Welfare policies that are directly or indirectly related to age or stages in the life-course attempt to compensate for variation in the income-generating potential over the life-course as well as for variation in economic needs associated with different ages and life-phases. Old-age pensions, for instance, compensate for the typical decline in the capacity for income generation in old age, while free or subsidised health care and social care address the tendency for both health care and social care needs to rise in old age. Similarly, economic redistribution in cash and inkind towards families with children can to some extent be seen as compensation for lower earnings potential of parents, and mothers in particular, due to care obligations towards children. More importantly, family transfers serve as compensation for higher economic costs of maintaining economically dependent children. This means that the income smoothing that welfare policies bring about should be interpreted not only in the narrow sense of levelling out fluctuations in income streams over the life cycle. In the broader sense, it is about aligning the access to economic resources with age-related variation in economic needs.

Income smoothing over the life cycle that results from age-related welfare policies should be distinguished from redistribution of lifetime income between the rich and the poor and, more generally, between individuals with different social characteristics and lifetime prospects. We might call the first within-individual reallocation of lifetime income and the second between-individual redistribution of lifetime income (Daniels, 1983). The former kind of redistribution is sometimes 
referred to as horizontal redistribution. By contrast, the latter (vertical) redistribution reduces differences between individuals situated at different ends of the income distribution (Palme, 2006).

Some of the within-individual reallocation of lifetime income achieved by the welfare state could in theory be achieved voluntarily and individually through the capital market, by families taking up loans to cover their higher-income needs in the child-rearing phase and by people saving for retirement. However, most welfare states engage rather heavily in the reallocation of resources and consumption possibilities across age groups. The involvement of the state can either be justified with reference to market failures and (soft) paternalistic considerations (see Daniels, 1983, p. 404 ff.) or with reference to intrinsic concerns about the distribution of resources and economic wellbeing between age groups at a particular point in time (McKerlie, 2012). A third possibility is that policies that reallocate resources across age groups and hence over the life cycle open up possibilities to pursue some degree of vertical redistribution of lifetime income between individuals as a kind of side effect (Rødset, 2004). ${ }^{1}$ However, this does not really amount to a justification, and it begs the question of why vertical redistribution of lifetime income is perceived to be more politically feasible when integrated with schemes that primarily appear to redistribute resources across age groups and, hence, over the life cycle.

It should be acknowledged at the outset that individuals belonging to different age groups at a particular point in time also belong to different birth cohorts. While age groups have a regularly changing composition of members, the membership of any given (societal) generation or birth cohort is fixed. Distribution and redistribution across age groups at a particular point in time will therefore inevitably involve distribution and redistribution between individuals belonging to different overlapping generations. Using tax revenue to finance old-age pensions and elderly care or to give economic support in cash or in-kind to families with children involves redistribution of economic resources in favour of, respectively, old and young age groups, who at the same time belong to specific generations. The age groups in the middle, who themselves represent a specific generation, are asked to carry the financial burden. Only in a highly hypothetical steady state in terms of policy, macroeconomics, and demographics can it be assumed that policies that redistribute economic resources towards a particular age group or lifephase will be approximately neutral in a generational perspective and only result in within-individual income reallocation over the life cycle.

In this chapter, we are interested in the normative issues that arise in connection with welfare policies that have redistribution across age groups and reallocation of economic resources over the life cycle as their primary purpose. Welfare state policymakers constantly face difficult questions concerning how much redistribution is justified in favour of particular age groups and life-phases. In Chapter 3, Bay and Pedersen show that there is wide variation across contemporary European welfare states in the share of economic resources devoted to pensions and social services for the elderly, on the one hand, and the share of economic resources devoted to transfers and services to families with children, on the other. 
In the past decades, the sceptre of population ageing and financial austerity has in many countries led to the legislation and implementation of pension reforms that are intended to limit or reduce the present and future growth in public expenditure on old age pensions and hence reduce the financial burden on future taxpayers (Ebbinghaus, 2011). Although contemporary pension reforms are designed primarily to have long-term effects that will fully unfold in the coming decades, we can now observe that in some countries, per capita expenditure on old age pensions has declined in recent years, while it has continued to grow in other countries at a decreasing pace. At the same time there are in many countries debates about how far the state should take responsibility for directly providing care for the elderly or subsidising privately provided care. Here, the cross-national policy differences are wide, but with some tendencies for upward convergence among the European countries (OECD \& European Union, 2018, pp. 136-137). Debates about pension reforms and reforms in elder care obviously raise difficult normative issues about the priority given to (older) pensioners versus (younger) taxpayers and present versus future generations taxpayers/pensioners. They often explicitly refer to notions of intergenerational fairness and ideas about what a desirable "generational contract" underpinning the pension system and the overall welfare state should look like.

Public expenditure on family policy in general, and on childcare in particular, has in the past decade been growing in many countries, although from a very low level in Continental and Southern Europe and a significantly higher level in the Nordic countries (Schoyen, 2016). The patterns of variation over time and between countries in the priority given to providing or subsidising childcare are to some extent driven by the changes in the level of female labour force participation. However, in addition to this material/functional explanation, the widespread tendency towards growth in expenditure on family policy and children is arguably reinforced by a normative/ideological shift in the form of increasing political awareness across Europe of a normative obligation to combat child poverty and "invest" in children's social and cognitive development - as exemplified by the European Commission's initiative to promote investment in children as an important part of the so-called Social Investment Package (European Commission, 2013; see also Morel et al., 2011).

In this chapter, we address these more general normative issues by discussing and applying two competing theories about fairness in the distribution of economic resources between overlapping generations: Daniels' "prudential lifespan account" (Daniels, 1983, 1988, 2008) and McKerlie's demand for "equality between age-groups" (McKerlie, 1989, 2001, 2012). We try to relate these two rather abstract theories to two very specific policy developments in contemporary Norwegian welfare policy: (a) the conversion of the implicit generational contract in connection with the major old-age pension reform that was enacted in 2009 and (b) the gradual transformation of the package of economic support for families with children away from cash transfers (child allowance) and over to free or subsidised services (public childcare and after school programmes).

The chapter is organised as follows: In the next section we introduce the two contemporary Norwegian policy developments and the associated debates. We 
complete the introduction of each case with what we believe are pertinent normative questions. Next, we present Daniels and McKerlie's theories before we return to the Norwegian case and discuss how each of the two contemporary debates and the associated questions can be interpreted in light of the two contrasting theories. Finally, we try to use the application of the theories to our two practical cases as a point of departure for suggesting a compromise or synthesis of the two competing positions that can be used as a guide to approaching critical normative issues involved in contemporary debates on family policy and pension policy.

\section{Two contemporary policy issues}

The first specific policy issue that we shall address here is related to a major, structural reform of the Norwegian old-age pension system that was legislated in 2009 and started to take effect from 2011. The reform was motivated by growing concerns about the long-term financial sustainability of the existing pension system that had been established in 1967, offering a combination of universal minimum pensions and earnings-related supplementary pensions based on pay-as-you-go financing. Due to the familiar combination of lower fertility and increased longevity, the continuation of the system was projected to result in rather dramatic increases in pension expenditure over the 21 st century. In the early 2000s, calculations showed that total old-age pension expenditure would increase from $6 \%$ in 2000 to $15.2 \%$ of GDP in 2050 (Official Norwegian Report (NOU) 2004:1, 2004), and that the financing of the system in 2050 would require contributions from the economically active population equivalent to $29 \%$ of the total wage sum (Pedersen, 2013; cf. Fredriksen et al., 2008).

A key element of the reform is the introduction of a new principle of longevity adjustment of benefits, which means that annual retirement benefits will be reduced in line with gains in longevity for successive birth cohorts. The reform, and in particular the introduction of longevity adjustment, implies a redefinition of the implicit generational contract of the pension system. The old system promised a certain annual replacement rate from a fixed retirement age. By contrast, the new system promises a certain total amount of accumulated pension wealth to be distributed over the (expected) duration of the retirement phase. Younger cohorts with a successively higher life expectancy will be required to accept lower annual benefits since the accumulated pension wealth will be spread more thinly over the retirement phase. Alternatively, they can postpone retirement in order to receive the same annual benefits (replacement rate) as was promised in the old system. In either case, the costs of increasing longevity have been transferred from the working-age taxpayers to the pensioners. Other demographic and economic risks that are associated with a pay-as-you-go pension system, like changes in fertility or the wage sum, are still residing with the taxpayers, as the new pension system is fully integrated with the general state budget. Even so, it is projected that the reform will reduce public expenditure on old-age pensions by $25 \%$ in 2050 , partly due to lower average benefits and partly to increases in the effective retirement age (Christensen et al., 2012). 
While the pension reform and the introduction of the mechanism of longevity adjustment appear to have been widely accepted by societal stakeholders and by the general public before the enactment of the reform, few attempts have been made to provide this important aspect of the pension reform with a more profound and principled justification (Pedersen, 2013). Consequently, the reform is vulnerable to growing critique as the effects of the reform will gradually become more severe and visible for successive new pensioner cohorts.

\section{Question 1: Is it justifiable to let future cohorts of old age pensioners carry the full costs of increasing longevity and, if so, under what conditions?}

The second policy debate that we want to address is concerned with the level and composition of welfare state support for families with children. Over the past two decades, the level of public expenditure on support for families with children has remained fairly stable in Norway when measured as a percentage of GDP. The composition has changed, however, in favour of childcare services that can be seen to contain an important investment aspect - both here and now by freeing up the parents' time to participate in full-time employment and, particularly, in the long-term by contributing to the cognitive and social development of children (Official Norwegian Report (NOU) 2017:6, 2017; Schoyen, 2016). The increased emphasis on "social investments" in the policy package directed towards families with children over the past decades has been associated with and arguably implicitly financed by a gradual reduction in the real value of cash transfers granted to families with children. Particularly relevant in this regard is the universal child allowance that was first introduced in 1946. Since 1996, the nominal values of the allowance have been frozen with an associated severe decline in terms of both real purchasing power and its relative importance in the income packages for families with children. While the nominal value of the child allowance remained constant between 1996 and 2018, average nominal wages increased by 140\% in the same period. In order to return the real value of the child allowance to the same level of generosity as in 1996, the annual benefits received for one child would in 2018 have had to be increased from just above kr10 000 (approximately $€ 1000$ ) to kr24 000 (approximately €2400).

Simultaneously and presumably partly as a result of this development, the level of financial poverty among families with children has been rising, in particular among single-parent families. While the rate of financial poverty among families with children used to be lower than in the general population, it is now significantly higher as shown in Figure 2.1.

The gradual decline in the value of child allowance has taken place with little debate under different governments. This reduction of cash transfers has gone hand in hand with increased expenditure on childcare services, securing virtually full coverage for children under school age, at strongly subsidised prices. Thus, there seems to be a broad and more or less tacit consensus about a narrative that the Norwegian welfare state has even increased its efforts in support of families with children over the past decades. 


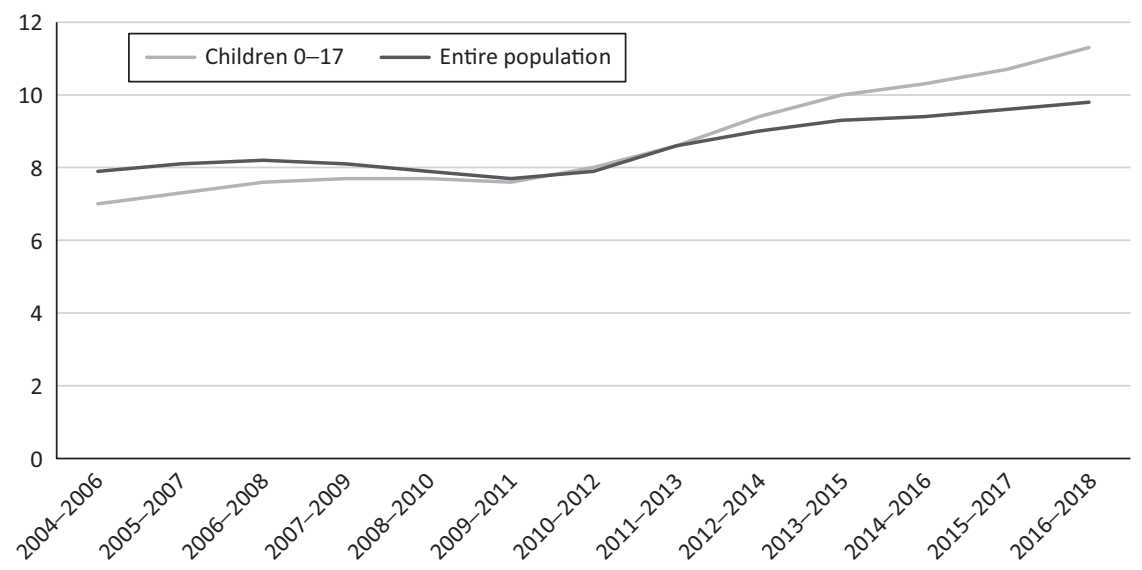

Figure 2.1 The financial poverty rates according to EU's “At Risk of Poverty" indicator applied to incomes summed over a three-year accounting period. Source: Statistics Norway.

The common acceptance of the decline in cash transfers to families with children and the political complacency with the associated increase in financial poverty rates among children seem to receive justification in recent research contributions. Aaberge et al. (2019) show that when taking into account the (increasing) value of the services that the families, poverty rates among families are lower than that indicated by conventional measures and do not show the same tendency to rise. The findings seem to suggest that the increase in financial poverty is in reality just an artefact that arises due to the narrow conception of income in conventional poverty measures.

What is lacking in this debate, however, is a principled framework for discussing how the overall level of support for families should be determined, and whether it is relevant to include the value of investment-oriented services in the measurement of financial poverty and economic wellbeing of families here and now. The pertinent normative question in this case can be framed as follows:

Question 2: Is it justifiable to let increasing expenditure on early childhood care and education be indirectly financed by a decrease in the level of cash transfers to families with children, and should the economic value of the educational and care services received by families with children be counted in the measurement of their incomes and hence in the assessment of financial poverty?

We believe that debates about both the pension system and family policy can benefit from more principled thinking along the lines of the two competing theories about a fair distribution and redistribution between age groups to which we now turn: Daniels" "prudential lifespan account" and McKerlie's demand for "equality between age-groups". 


\section{Presentation of the two theories}

The theories that we are about to present share some core ideas that distinguish them from other important theories in political philosophy about distributive justice. Many prominent political philosophers either state explicitly or take for granted that theories about distributive justice should only be concerned with the distribution of lifetime income and economic wellbeing more generally between individuals. McKerlie refers to this commonly held position as "complete lives egalitarianism". The exclusive emphasis on complete lives is very explicitly developed by Thomas Nagel (1970), but it is also present in the respective theories of John Rawls (1971) and Ronald Dworkin (1981a, 1981b). The claim that egalitarianism should focus on complete lives is supported by the intuition that goods enjoyed at a particular point in time by an individual can fully compensate for the lack of similar goods enjoyed at another time. A core idea among egalitarian philosophers is precisely that a similar intuition does not apply to the situation where goods are unequally distributed or transferred between different individuals.

Both Daniels (1983, p. 500) and McKerlie (2012, p. 21 ff.) reject this "complete lives egalitarianism" by insisting that social justice is not achieved only by securing a just distribution of lifetime income and economic wellbeing within and between generations. Instead, they both argue that also the distribution of resources or annual incomes or wellbeing across age groups in a society at a particular historical moment is a moral concern in its own right. ${ }^{2}$ However, they differ strongly in the way they frame the argument in favour of making the distribution between age groups and life-stages morally relevant in its own right and in their specific conception of a just distribution of economic resources across age groups and overlapping generations.

\section{Daniels' theory: "the prudential lifespan account"}

Norman Daniels $(1983,1988,2008)$ has proposed a highly influential theory on how to think about the distribution of scarce resources between individuals belonging to different age groups. His seminal article on the topic (Daniels, 1983) was primarily concerned with the allocation of health care services between individuals of different ages and whether it could be justified to discriminate between patients according to age, for instance, by withholding certain expensive and at the same time potentially life-saving treatments from patients above a certain age. He discusses how discrimination according to age has both similarities and fundamental differences with discrimination according to gender and race. The most fundamental difference is that an individual over time can expect to live through the different life-phases, while this is obviously not the case for gender, race, and social class. This implies that thinking about the distribution of resources across individuals at different ages can be reframed as being analogous to a question about how resources should ideally be allocated over the life-course of a single individual. This is the core idea of Daniels' theory about what constitutes a just 
distribution of resources between age groups: it is the distribution over different ages and stages in the life-course that a prudential individual would choose for him/herself behind a kind of "veil-of-ignorance" about individual characteristics (including age) and preferences (Daniels, 1983, p. 509) - akin to the more famous contractual theory of justice developed by Rawls (1971).

Daniels needs to make a number for further assumptions in order to arrive at substantial conclusions from this basic framework for thinking about issues of distribution and redistribution across age groups. He takes as a point of departure the principle of equal concern given to all life-phases. In other words, he avoids that the deliberation about a prudential distribution of resources over the lifespan takes the time of birth as a point of departure and applies some sort of discounting to weight costs and gains experienced at different points in the lifecourse. Instead, the age perspective of the deliberation is made neutral by also including age in the set of information that is kept behind the veil of ignorance. The deliberation does, however, take account of knowledge about the length of the "normal lifespan", and Daniels proposes that the deliberators will be concerned with attempting to maximise his/her opportunity range at each particular age/life-phase (Daniels, 1983, p. $508 \mathrm{ff}$.). The idea is to build in a recognition that the range of opportunities available for the individual will naturally differ with age. This further implies, according to Daniels, that the deliberators will be concerned with maximising his/her probability of reaching a normal lifespan, but not with prolonging life further beyond this threshold that can be roughly associated with the normal life expectancy. Based on this framework, Daniels claims to have established a theory that could justify excluding persons above a certain age from receiving expensive life-prolonging treatments if the resources that are liberated instead are used to develop other treatments that will increase the likelihood of reaching what can be considered the normal life expectancy in a given society.

Of interest here is not so much the specific conclusion that Daniels arrives at with respect to prioritising health care services, but more the general suggestion to look at the issue about a just distribution across age groups as an issue of a prudent allocation of resources over the lifespan of individuals. A prudent agent who gives equal weight to all life-phases will be prone to consider efficiency, i.e. how to achieve the highest economic returns overall, when contemplating how to allocate economic resources over the life-course. In other words, an uneven distribution of resources between age groups and life-phases can be justified if it contributes to enhancing the welfare of individuals in a lifetime perspective.

However, it is not entirely clear how strongly Daniels' prudent agents would emphasise efficiency in the allocation of resources over the life-course. Presumably, they would land somewhere in the range between a utilitarian principle of maximising the sum of welfare for all agents over all life-phases and adopting a maximin criterion with respect to welfare enjoyed in different life-phases in the spirit of the difference principle in Rawls' theory.

In any case, prudence would require that investing resources at a particular age or life-phase should be made if they are likely to give a high return in a lifetime perspective, and therefore the investments should be seen as such and not as 
an unfair privilege granted to the age/life-phase where the investment is made. Although concerns for efficiency in a lifetime perspective are taken in in order to justify a possible non-egalitarian distribution of resources over the life cycle and hence across age groups, Daniels' position still deviated from standard "complete lives egalitarianism" by insisting that the distribution across age groups is an intrinsically moral concern. The argument is that prudence constrained by an equal concern for all life-phases should be the guide to distributive justice across age groups.

\section{McKerlie's theory: "equality between age groups"}

By transforming the problem of distribution across age groups from a betweenindividuals distributive issue to the problem of prudent within-individual allocation over the life-course, Daniels' theory allows for an uneven distribution of resources between age groups and downplays distributive concerns related to coexisting generations in favour of emphasising efficiency in a life-course perspective. This has led to critique from a number of scholars, including among others Anderson (1999) and Pettit (2012), who insist on the importance of minimising inequality across simultaneously living age groups or overlapping generations at any particular point in time as an important concern in itself. The most elaborate critique of Daniels' theory and proposal for an alternative theory of justice between age groups has been put forward by Dennis McKerlie in a number of articles $(1989,2001)$ and a book (2012).

McKerlie's critique of the prudential lifetime account centres on a rejection of the idea to transform the issue of distribution between life-phases into an issue of prudence and perhaps even efficiency in a lifetime perspective. His critique echoes the standard egalitarian critique of utilitarianism for offering the maximisation of the sum of welfare across individuals as the guide to the distribution of resources between individuals (McKerlie, 2012, pp. 41-47). McKerlie argues that even if Daniels assumes that the prudential deliberation takes place behind a veil of ignorance also concerning the individual's age, and hence, that the result should be neutral in terms of the priority given to each life-phase, the theory would still recommend more resources devoted to early and middle life at the expense of old age, because allocating resources to earlier life-phases is likely to have an investment component that is lacking when giving resources to the very old.

McKerlie's theory claims, by contrast, that we should be intrinsically concerned with inequality in income and living conditions between age groups and coexisting generations in a society at any given historical moment. He defends a position where egalitarianism is extended to not only refer to the distribution of lifetime income/welfare (as in "complete life egalitarianism") but also to the distribution across temporal parts (segments) of life, what we commonly refer to as age groups. In particular, he defends the so-called simultaneous segments view whereby comparisons between contemporary age groups have direct moral relevance (McKerlie, 2012, p. 61). According to this theory, inequalities between young and old at a point in time are objectionable, even if they should turn out to 
cancel out in a lifetime perspective. A transfer of resources between age groups - say a child allowance or an old-age pension - is justified if it contributes to reducing inequality in wellbeing across age groups here and now. A transfer that is equalising in this respect might at the same time lead to more inequality across the respective birth cohorts in a lifetime perspective. Hence, there might be a conflict between these two egalitarian objectives. McKerlie recognises this, and he makes it clear that his position does not imply that potential effects on the distribution of lifetime income should be ignored or overridden, only that the effects on the distribution here and now between age groups are morally relevant in itself and should somehow be counted in. It is morally objectionable if a particular age group is relatively disadvantaged vis-à-vis other age groups, even if this disadvantage is compensated during other life-phases and even if it cancels out in a lifetime perspective.

A practical implication of McKerlie's theory is that it, in certain contexts, recommends that more resources are devoted to the elderly, compared to the recommendation that would follow from Daniels' prudential approach. McKerlie's theory could in principle lead to a recommendation that support for the elderly should be increased - given that their situation is particularly disadvantaged visà-vis other age groups - even if this redistribution in favour of the elderly would lead to some reduction in lifetime welfare for all cohorts/generations in a steadystate continuation of the policy.

\section{Key differences and room for compromise?}

The theory of Daniels puts concerns for efficiency and the maximisation of welfare in a lifetime perspective at the centre of considerations about age-related welfare policy, while the theory of McKerlie insists on weighing in intrinsic distributive concerns, including considerations for equality in income and wellbeing across coexisting individuals in different age groups and, hence, overlapping generations.

However, although the theories are clearly competing, there might be room for compromise because the initial basic focus of the two theories is different. The theory of Daniels is primarily concerned with the distribution of scarce resources across individuals in different age groups. The more or less implicit contrast is between a uniform distribution (no discrimination) on the one hand and giving some priority to specific age groups out of concerns for efficiency in a lifetime perspective on the other. McKerlie's theory, on the other hand, takes existing inequalities in the distribution of wellbeing across age groups in a given society as the point of departure, and develops the case for correcting these inequalities (by redistribution according to need at any given point in time). It can be argued therefore that the two theories are only in direct conflict with each other if and when investing resources at a particular age with a view to increasing lifetime welfare (as recommended by Daniels' theory) is associated with increased inequality at the level of welfare enjoyed by different coexisting age groups (condemned by McKerlie's theory), or to the extent that resources spent on correcting cross-age 
inequalities could alternatively be spent on investments that lead to an improvement in lifetime prospects.

\section{Application to the two cases}

\section{Longevity adjustment of old age pensions - under what conditions is it defensible?}

The economist Richard Musgrave showed in a seminal article how the generational contract of a pay-as-you-go pension system, where current old pensions are financed directly by taxes/contributions paid by the economically active population, can be set up according to three distinctive principles (Musgrave, 1981). The first alternative principle he calls "Fixed Replacement Rate", and it corresponds to the main characteristics of classical ("defined benefit") social insurance schemes. The scheme promises pensioners a certain replacement rate in retirement (that the annual pension benefit will amount to a certain fraction of the previous wage) and benefits are paid lifelong from a certain age. On the financing side, the collection of taxes and contributions from the economically active population is constantly adjusted in order to collect the necessary revenue to cover pension expenditure. In this ideal-typical system, all demographic and economic risks of the pension system are carried by the economically active population. If, for instance, longevity increases (leading to higher pension expenditure) or fertility declines (leading to lower revenues), the rate of taxes and contributions on the economically active population has to be increased. As a consequence, the disposable incomes of the economically active population will decline relative to the contemporary pensioner generation that continues to enjoy the same level of benefits as promised by the scheme. The second alternative, "Fixed Contribution Rate", is the complete opposite of the first alternative. Here the system is built around a fixed contribution rate on the economically active population, and the level of benefits offered to the current generation of pensioners will depend on the size of revenues generated by the fixed contribution rate at a particular point in time and on the number of pensioners among whom the total revenues should be shared. In this ideal-typical scheme, all economic and demographic risks of the pay-as-you-go pension system are transferred from workers to pensioners. If longevity increases or fertility drops, the annual benefits paid out to each old age pensioner will have to be lowered in order to make sure that total pension expenditure matches the revenues generated by the fixed contribution rate. As a matter of fact, a version of this principled solution to the problem of the generational contract has been realised in the reformed Swedish pension system (Pedersen, 2005). Finally, Musgrave proposes the principle of "Fixed Relative Positions" as an attractive third alternative. This principle entails a perfect sharing of all economic and demographic risks between workers and pensioners. It can, for instance, be realised by letting the pension system be financed by general taxation with mechanisms to ensure that tax rates on workers and pensioners are adjusted proportionally to meet changes in pension expenditure, or changes in the tax base. In this case, if longevity increases or fertility drops, both the economically active 
and the pensioners will have to suffer a (similar) decline in annual disposable incomes.

Musgrave's principle of Fixed Relative Positions is in perfect alignment with McKerlie's theory. It ensures that at any given point in time, the ratio of disposable income levels enjoyed by the young and the old will remain the same. At the same time, the Musgrave principle completely ignores fluctuations over time in the level of income available for the equal distribution between age groups (see Myles, 2003; Oksanen, 2003; Schokkaert \& Van Parijs, 2003). In particular, it should be noted that increasing longevity will lead to strong increases in aggregate pension expenditure, and consequently to decreasing disposable incomes for both the economically active population and for pensioners; and this raises the question of whether it would not be in the interest of both age groups in a lifetime perspective to postpone the transition from work to retirement in line with increases in longevity.

This is why John Myles (2002) has argued for modifying the Musgrave principle by letting the longevity risk be carried exclusively by pensioners. If longevity increases are associated with improved health and functioning at specific ages, then Daniels" "prudential lifespan" perspective can be invoked to support the principle of longevity adjustment as a reasonable modification to the Musgrave principle. A prudential individual deliberating behind a veil of ignorance is likely to prefer working longer when longevity increases in order to uphold the same living standard as before (both while working and in retirement), rather than simply expanding the retirement phase and accepting lower annual incomes both before and after retirement.

The mechanism of longevity adjustment that is built into the new Norwegian pension system can be justified in this way. In the new Norwegian pension system, the longevity risk has been transferred to each pensioner cohort, while the sharing of the remaining risks (for instance, fertility and macro-economic developments) remains rather opaque since the pension system is fully integrated into the state budget without a clear specification how increasing pension expenditure will be shared between workers and pensioners.

In any case, the longevity adjustment that is built into the reformed Norwegian pension system can be justified with reference to prudential reasoning in a lifetime perspective. However, it should be emphasised that this argument rests on a crucial assumption: that the possibilities to work at specific ages improve in line with improvements in longevity. If the age at which the disutility of working increases and productivity decreases remains constant while longevity increases, the prudential individual would not postpone retirement. Longevity adjustment would, in this case, impose a strong decline in incomes in retirement in violation of McKerlie's claim for equality between age groups. The assumption would also be violated if employers and the labour market institutions more generally do not adjust to allow workers to postpone retirement in line with changes in longevity. McKerlie's concern for equal treatment and equal outcomes across age groups comes into full force if the link between improvements in longevity and improvements in the functional capacity for work and the actual opportunities offered at 
different ages is weak. Whether this is in fact the case is an empirical question that has not been firmly settled (however, for a study that lends some support to the hypothesis that the prevalence of functional disabilities at a particular age tend to decline with increasing longevity, see Moe \& Hagen, 2011).

\section{Is it justifiable to let cuts in the child allowance programme finance increasing expenditure on services to families with children?}

The social investment paradigm that became prominent in social policy debates both among academics and policymakers from the mid-1990s promises to overcome the dilemma between "neo-liberal" concerns for advancing employment, economic growth and economic efficiency, and upholding or expanding redistributive social policies (Birnbaum et al., 2017; Morel et al., 2011). The precise content of the social investment argument is not always entirely clear, and the same can be said about the policy recommendations that follow from the argument. Sometimes the argument is simply invoked as a justification for existing social policies, claiming that they have positive implications for economic growth in the long run. At other times it is used to justify changes in social policy interventions in favour of measures that are assumed to enhance employment rates and productivity in the long run. This ambiguity is revealed in debates about family policy. The social investment paradigm lends support to the idea of expanding the availability of affordable formal childcare and to transform it into an arena for promoting the development of social and cognitive skills from an early age (for highly influential contributions, see Esping-Andersen, 2002; Heckman, 2008). It is more unclear what the paradigm implies for existing cash transfer programmes towards families with children like traditional universal or means-tested cash transfer programmes. Does the paradigm justify cuts in these schemes in order to concentrate resources on educational programmes for small children, or could also cash transfers to families with children be justified as investments in the future productivity of children? The problem for the latter option is that it rests on strong factual claims about the relationship between cash transfers to families with children and the future outcome of the children that might be true but have been difficult to support with hard empirical evidence (Mayer, 1997; cf. Cooper \& Stewart, 2020).

This is precisely the dilemma that comes to the fore in our second Norwegian debate. Norwegian policymakers tend implicitly to take the first view. The large effort to expand coverage with preschool day care, and the simultaneous decline in the value of the child allowance over the past decades in Norway, is seen as a legitimate redirection of economic support to families with children. This view is indirectly supported by a new approach to the measurement of income inequality and poverty suggested by Aaberge et al. (2019). The approach entails adding the value of publicly provided or sponsored services to the measurement of total equivalised household income. Using this approach, the authors show that the level of income poverty prevailing among families with children is very dramatically reduced when taking into account the value of subsidised childcare and free 
primary school that is received by families with children. This is so even if the authors take measures to adjust the implicit assumption about the economic needs of different household types to take into account also the need to provide children with care and education. The reduction in measured poverty rates arises because the value of these services is uniform across families with a fixed number of children in the relevant age groups, while it is assumed that the economic needs for these services are proportional to household incomes.

Also, in relation to this debate, we believe that a combination of the theories of Daniels and McKerlie can help clarify the issues involved and suggest a constructive compromise. Investing in children's social and cognitive development is easily justified with reference to Daniels' "Prudential lifespan account". McKerlie's insistence on "Equality between age groups" can, on the other hand, be invoked to reject the idea that increased investments in children's long-term outcomes should be made at the expense of the living conditions of families with children here and now. Maintaining a clear distinction between investments in future outcomes and support to achieve an acceptable living standard here and now is key to the solution proposed here. Cash transfers to families with children are motivated by the goal to compensate families with children for their higher consumption needs and lower income-generating capacity, while educational services can be motivated as social investment.

Increasing investment in children can be justified in the spirit of Daniels' "prudential lifespan account", but it should not be done at the expense of cash transfers to families with children that are instrumental in avoiding widespread financial poverty among families with children here and now. Families with children should be helped to maintain the same level of economic wellbeing as other demographic groups in line with McKerlie's theory. Moreover, following McKerlie's line of reasoning, it becomes fundamentally misleading to include investments in schooling when measuring economic wellbeing among families. A defence for maintaining (or expanding) the quality of a traditional child allowance scheme could, therefore, in the first instance refer to the ideal of "equality between age groups" and not make itself solely dependent on empirically fragile and hence contestable claims about effects on future outcomes.

\section{Conclusions}

For the past 20 years or so, European governments have been concerned with making adjustments to the challenges posed by population ageing. Old age pension systems and family policy have represented two main areas of intervention. Pension reforms have aimed to reduce projected future public pension expenditures, above all by increasing workers' incentives to retire later or, alternatively, accept lower annual benefits. In family policy, we have seen a turn towards an expansion of childcare to facilitate the reconciliation of work and family and, thereby, stimulate higher labour market participation and, potentially, even fertility. Such developments would, in turn, affect positively the long-term sustainability of the welfare state. 
More generally, welfare states redistribute income across age groups at any given point in time as well as both within and across generations in a life-course perspective via different policy instruments targeted at different ages. Such cash benefits and in-kind services determine how welfare states treat generations and age groups, and thus, they have implications for the (implicit) generational contract around which the modern welfare states are constructed.

Against this backdrop, this chapter has suggested that the debate about benefits and services that have age or life-phase as a point of reference for determining eligibility would benefit from a discussion about the normative principles that underpin the allocation of economic resources to different ages and overlapping generations, even if these principles are not always articulated explicitly. In this context, we have argued that Daniels and McKerlie offer two coherent but contrasting approaches to the question of how to fairly distribute economic resources across overlapping generations. The two perspectives have been influential in theoretical debates, and in this chapter, we have demonstrated how normative theories of this kind may also contribute to a theoretically informed discussion of real-world examples of age or life-phase-oriented policy. An explicit treatment of normative issues is often missing in public discussions of sometimes quite technical and complex welfare schemes (perhaps particularly true in the case of pensions).

On the one hand, for Daniels, a just distribution across age groups is obtained if the existing policies produce the kind of outcomes that would be preferred by prudent individuals when contemplating how to allocate resources over their own life-course. This goal might, in certain situations, justify a disproportional allocation of investments to a specific age group if it entails significant efficiency gains from a life-course perspective. The mentioned turn towards social investment in social policy, represented most notably by governments' increased efforts to expand and support early childhood education and care, is arguably the most prominent example of this kind of logic put into practice.

On the other hand, McKerlie underlines the importance of inequality in living conditions between age groups at a given point in time as a moral question in itself. Even if differences between age groups should tend to cancel out when adopting a life-course lens, it is problematic if there, at a given moment, are large differences across coexisting age groups with regard to incomes and living conditions more generally. We have argued that McKerlie's theory is in line with Musgrave's warning against letting the economic risks inherent in a payas-you-go pension system fall exclusively on either workers or pensioners and in agreement with Musgrave's suggestion for an equal sharing of risks between overlapping generations. Also, the example of the weakening of the Norwegian child allowance together with the more or less simultaneous steady increase in child poverty brings to the fore the practical relevance of McKerlie's arguments.

In our discussion of theories and their application to the two practical cases we have suggested that even if the theories of Daniels and McKerlie are competing, there is room for a compromise between the two that can give crucial normatively grounded guidance in decisions about age-based welfare policies. Following 
Daniels, especially in a context of tight budget restraints, it makes sense to strive for an efficient allocation of resources, considering the whole life of individuals. However, inequalities (or lack of redistribution) across age groups at a specific moment in time may be bad both in terms of social justice and political sustainability. If one age group sees that poverty rates are growing fast, they will expect the government to react. Failure to do so can create popular discontent and unrest and may make otherwise sensible and necessary policy reforms more difficult to design and sell politically.

While the chapter has discussed two examples from contemporary Norwegian policy debates, questions of inequality across age at a given moment in time and across generations in a lifetime perspective are relevant to most mature welfare states and are not likely to go away. Life expectancy is increasing and is something pension systems across Europe have to address. The same can be said about the need to find the right mix of support for families with children in a time of growing income inequalities. Social investment with its emphasis on education to improve future life chances is by now a consolidated and relatively uncontroversial part of the solution. However, as the Belgian economist Bea Cantillon reminds us, "this must not stop us from locating shortcomings and problems, as [...] the investment turn, too, did not deliver on poverty alleviation" (Cantillon, 2013). Traditional forms of social protection need to be preserved so that they can operate in parallel with social investment (Cantillon \& Van Lancker, 2013). In short, economic redistribution across overlapping generations is not a question of either-or. We can draw on the theories of both Daniels and McKerlie to strike a reasonable balance between considerations of income and wellbeing over the life-course and the preservation of equality in living conditions across overlapping generations here and now.

\section{Notes}

1 Typically, the aim would be redistribution from rich to poor, but vertical redistribution can also in practice go in the opposite direction. In that case the outcome is sometimes described as "perverse" redistribution (Palme, 2006).

2 The focus does not have to be literally on annual incomes but on incomes received at a particular point in time irrespective of the exact length of the accounting period (one, two, or three years).

\section{References}

Aaberge, R., Eika, L., Langørgen, A., \& Mogstad, M. (2019). Local governments, in-kind transfers, and economic inequality. Journal of Public Economics, 180, 103966. https:// doi.org/10.1016/j.jpubeco.2018.09.015

Anderson, E. S. (1999). What is the point of equality? Ethics, 109(2), 287-337. https://doi .org/10.1086/233897

Birnbaum, S., Ferrarini, T., Nelson, K., \& Palme, J. (2017). The generational welfare contract. Edward Elgar Publishing. https://www.elgaronline.com/view/978178347102 7.xml

Cantillon, B. (2013). Beyond social investment. Which concepts and values for social policy-making in Europe? In B. Cantillon \& F. Vandenbroucke (Eds.), Reconciling 
work and poverty reduction (pp. 286-318). Oxford University Press. https://doi.org/10 .1093/acprof:oso/9780199926589.003.0010

Cantillon, B., \& Van Lancker, W. (2013). Three shortcomings of the social investment perspective. Social Policy and Society, 12(4), 553-564. https://doi.org/10.1017/S14747 46413000080

Christensen, A. M., Fredriksen, D., Lien, O. C., \& Stolen, N. M. (2012). Pension reform in Norway: Combining an NDC approach and distributional goals. In R. Holzmann, E. Palmer, \& D. Robalino (Eds.), Nonfinancial defined contribution pension schemes in a changing pension world (1-0, pp. 129-157). The World Bank. https://doi.org/10.1596 /9780821388488_CH04

Cooper, K., \& Stewart, K. (2020). Does household income affect children's outcomes? A systematic review of the evidence. Child Indicators Research. https://doi.org/10.1007/ s12187-020-09782-0

Daly, M. (2018). Generations, age and life course: Towards an integral social policy framework of analysis. Contemporary Social Science, 15(3), 291-301. https://doi.org /10.1080/21582041.2018.1455107

Daniels, N. (1983). Justice between age groups: Am I my parents' keeper? The Milbank Memorial Fund Quarterly. Health and Society, 61(3), 489-522. JSTOR. https://doi.org $/ 10.2307 / 3349870$

Daniels, N. (1988). Am I my parents' keeper?: An essay on justice between the young and the old. Oxford University Press. https://books.google.no/books?id=_OoGORnv488C

Daniels, N. (2008). Justice between adjacent generations: Further thoughts*. Journal of Political Philosophy, 16(4), 475-494. https://doi.org/10.1111/j.1467-9760.2008.0032 0.x

Dworkin, R. (1981a). What is equality? Part 1: Equality of welfare. Philosophy \& Public Affairs, 10(3), 185-246. JSTOR.

Dworkin, R. (1981b). What is equality? Part 2: Equality of resources. Philosophy \& Public Affairs, 10(4), 283-345. JSTOR.

Ebbinghaus, B. (2011). The varieties of pension governance. pension privatization in Europe. Oxford University Press.

Esping-Andersen, G. (2002). A child-centred social investment strategy. In G. EspingAndersen (Ed.), Why we need a new welfare state. Oxford University Press. https://doi .org/10.1093/0199256438.003.0002

European Commission. (2013). Towards social investment for growth and cohesion - including implementing the European Social Fund 2014-2020 (Communication $\operatorname{COM}(2013) 83$ final). European Commission. 512730f61af12_Towards Social Investment for Growth and Cohesion - including implementing the European Social Fund 2014-2020.pdf

Fredriksen, D., Gunnes, T., \& Stølen, N. M. (2008). Oppdaterte framskrivinger av arbeidsstyrke, pensjonsutgifter og finansbyrde. Økonomiske Analyser, 27(4), 36-43.

Heckman, J. J. (2008). Schools, skills and synapses. Economic Inquiry, 46(3), 289-324. https://doi.org/10.1111/j.1465-7295.2008.00163.x

Kohli, M. (2006). Aging and justice. In Robert H. Binstock \& Linda K. George (Eds.), Handbook of aging and the social sciences (6th edition, pp. 456-478). Academic Press.

Mayer, S. E. (1997). What money can't buy: Family income and children's life chances. Harvard University Press.

McKerlie, D. (1989). Justice between age-groups: A comment on Norman Daniels. Journal of Applied Philosophy, 6(2), 227-234. https://doi.org/10.1111/j.1468-5930.1989.tb00 397.x 
McKerlie, D. (2001). Justice between the young and the old. Philosophy and Public Affairs, 30(2), 152-177.

McKerlie, D. (2012). Justice between the young and the old. Oxford University Press. https ://doi.org/10.1093/acprof:oso/9780199769131.001.0001

Moe, J. O., \& Hagen, T. P. (2011). Trends and variation in mild disability and functional limitations among older adults in Norway, 1986-2008. European Journal of Ageing, 8(1), 49-61. https://doi.org/10.1007/s10433-011-0179-3

Morel, N., Palier, B., \& Palme, J. (Eds.). (2011). Towards a social investment welfare state?: Ideas, policies and challenges. Policy Press. https://doi.org/10.1332/policypress /9781847429247.001.0001

Musgrave, R. A. (1981). A reappraisal of financing social security. In F. Skidmore (Ed.), Social security financing (pp. 89-127). MIT Press.

Myles, J. (2002). A new social contract for the elderly. In G. Esping-Andersen (Ed.), Why we need a new welfare state (pp. 130-172). Oxford University Press. https://doi.org/10 $.1093 / 0199256438.003 .0005$

Myles, J. (2003). What justice requires: Pension reform in ageing societies. Journal of European Social Policy, 13(3), 264-269. https://doi.org/10.1177/09589287030133004

Nagel, T. (1970). The Possibility of Altruism (Issue 86, p. 82). Oxford Clarendon Press.

OECD, \& European Union. (2018). Health at a Glance: Europe 2018. OECD Publishing and EU. https://www.oecd-ilibrary.org/content/publication/health_glance_eur-2018-en

Official Norwegian Report (NOU) 2004:1. (2004) Modernisert folketrygd-Bcerekraftig pensjon for framtida. Finansdepartementet og Sosialdepartementet. https://www.reg jeringen.no/contentassets/ebb8c70e34d84f5385e5a490f54835b1/no/pdfs/nou20042 0040001000dddpdfs.pdf

Official Norwegian Report (NOU) 2017:6. (2017). Offentlig støtte til barnefamiliene. Barne- og likestillingsdepartementet. https://www.regjeringen.no/no/dokumenter/nou2017-6/id2540981/

Oksanen, H. (2003). The debate on pensions: More rigour needed in the middle field. Journal of European Social Policy, 13(3), 269-273. https://doi.org/10.1177/095892870 30133005

Palme, J. (2006). Welfare states and inequality: Institutional designs and distributive outcome. Research in Social Stratification and Mobility, 24, 387-403. https://doi.org /10.1016/j.rssm.2006.10.004

Pedersen, A. W. (2005). Two technical choices with critical implications. Issues in Scandinavian pension reform (NOVA Skriftserie 6/05). NOVA Norwegian Social Research. http://nova.no/asset/862/1/862_1.pdf

Pedersen, A. W. (2013). Levealdersjustering av alderspensjonen - Økonomisk ansvarlighet og usosial populisme. In K. Ketscher \& A. Kjønstad (Eds.), Velferd og rettferd: Festskrift til Asbjørn Kjønstad el70 år (pp. 629-639). Gyldendal juridisk.

Pettit, P. (2012). On the people's terms: A republican theory and model of democracy. Cambridge University Press. https://doi.org/10.1017/CBO9781139017428

Rawls, J. (1971). A theory of justice. Harvard University Press; JSTOR. http://www.jstor .org/stable/j.ctvjf9z6v

Rødset, A. (2004). Appendix no. 7. Korfor obligatorisk pensjon? In Official Norwegian Report (NOU) 2004: 1, Modernisert folketrygd-Barekraftig pensjon for framtida. Finansdepartementet og Sosialdepartementet. https://www.regjeringen.no/contenta ssets/ebb8c70e34d84f5385e5a490f54835b1/no/pdfs/nou200420040001000dddpdfs .pdf

Rowntree, B. S. (1901). Poverty: A study of town life. MacMillan and co. 
Schokkaert, E., \& Van Parijs, P. (2003). Debate on social justice and pension reform: Social justice and the reform of Europe's pension systems. Journal of European Social Policy, 13(3), 245-263. https://doi.org/10.1177/09589287030133003

Schoyen, M. A. (2016). Den norske velferdsstaten: En sosial investeringsstat? Tidsskrift for Velferdsforskning, 19(01). idunn.no. https://doi.org/10.18261/issn.2464-30762016-01-01 